\title{
Analisis Indeks Koneksi Pasar dan Distribusi Margin Pada Lembaga-Lembaga Pemasaran Ternak Sapi Potong di Kabupaten Kupang Nusa Tenggara Timur Indonesia
}

\author{
Yakob R. Noach ${ }^{\mathrm{a}}$, dan Matheos Filipus Lalus ${ }^{\mathrm{b}}$ \\ ${ }^{a}$ Fakultas Peternakan, Universitas Nusa Cendana, Kupang-Nusa Tenggara Timur, Indonesia.Email: noach yakob@yahool.com \\ ${ }^{b}$ Fakultas Peternakan, Universitas Nusa Cendana , Kupang-Nusa Tenggara Timur, Indonesia.Email: matheoslalus@gmail.com
}

\section{Article Info}

Article history:

Received 4 Januari 2020

Received in revised form 13 Januari 2020

Accepted 18 Januari 2020

https://doi.org/10.32938/ag.v5i1.939

Keywords:

Index Koneksi Pasa

Farmer's share

Margin

\section{Abstrak}

Kegiatan lembaga perantara yang terlibat dalam pemasaran ternak sapi di Kabupaten Kupang-NTT antara lain: pembelian, pengangkutan, sortasi, standarisasi dan grading, dan sebagainya. Penelitian ini dilakukan dengan metode survai. Hasil penelitian ini : IMC antara harga ternak sapi potong di tingkat peternak dan pedagang perantara 1.0040; antara petani dan pedagang antara pulau 1.0048; antara pedagang perantara dan pedagang antar pulau 1.0714. Berarti dalam jangka pendek harga ternak sapi potong di ketiga pasar belum teritegrasi secara sempurna. Farmer's share sudah berlangsung cukup adil, meskipun pada berbagai tingkatan pasar ternak sapi di wilayah ini belum terintegrasi secara sempurna. Rata-rata farmer's share di wilayah penelitian adalah 75,95\%. Margin pemasaran adalah $62,17 \%$; profit margin sebesar $66.71 \%$. Profit margin terbesar diterima pedagang perantara adalah $60.70 \%$, pedagang antar pulau adalah $29.30 \%$. Distribusi margin pemasaran di antara pedagang perantara dan pedagang antar pulau masih timpang, di mana untuk pedagang perantara $88.57 \%$ dan untuk pedagang antar pulau $48.33 \%$

\section{Pendahuluan}

Barang dan atau jasa dari produsen hanya akan dapat mencapai konsumen, apabila melalui lembaga-lembaga pemasaran. Lembaga pemasaran merupakan penghubung di antara petani sebagai produsen ternak sapi dan konsumen daging sapi melalui kegiatan pemasaran. Ada berbagai kegiatan antara lain pembelian, pengangkutan, pengumpulan, sortasi, standarisasi dan grading dan lain sebagainya (Dahl dan Hammond, 1977; Djoko Susilo dan Bahari, 2012).

Jika keterlibatan setiap lembaga perantara dipandang sebagai pasar, maka diharapkan jika terjadi perubahan harga di pasar acuan (dalam hal ini pedagang besar penerima di Jakarta) dapat ditransmisikan melalui berbagai lembaga yang terlibat dalam pemasaran ternak sapi tersebut hingga di tingkat petani sebaga produsen ternak sapi secara sempurna. Hukum Satu Harga (LOP) bisa ditemukan pada semua pasangan pasar ternak co-integrasi menyiratkan bahwa, harga produk-produk pertanian sepenuhnya ditransmisikan antara pasar-pasar ini. Dengan demikian dapar dikatakan terintegrasi, jika terjadi perubahan harga di pasar acuan sebesar $1 \%$ akan ditransmisikan dengan persentase yang sama $\mathrm{d}$ tingkat petani sebagai produsen sapi potong. Dengan demikian dapat diduga pasar-pasar tersebut terkoneksi secara sempurna maupun tidak sempurna sebagaimana terjadinya integrasi tersebut. Muwanga dan Snyder (1997) menyatakan bahwa, pasar-pasar terintegrasi apabila ada aktivitas perdagangan antar dua atau lebih pasar yang terpisah secara spasial, kemudian harga di suatu pasar berhubungan atau berkorelasi dengan harga di pasar-pasar lainnya. Perubahan harga di suatu pasar secara spasial atau total ditransmisikan ke pasarpasar lainnya, baik dalam jangka pendek maupun jangka panjang.

Jumlah lembaga yang terlibat dalam pemasaran suatu produk pertanian akan menyebabkan semakin besarnya margin pemasaran. Karena setiap lembaga pemasaran (baik individu maupun kelompok atau lembaga) dalam kegiatan pemasaran mengeluarkan tenaga, biaya dan waktu dalam pelaksanaan berbaga fungsi pemasaran; seperti fungsi pembelian, fungsi penjualan dan fungsi fasilitas (Lalus, et al 2018). Sehingga harapan terhadap adanya keuntungan (marketing profit) merupakan konsekuensi logis dari segala pengorbanan yang telah dilakukan. Semakin besar margin pemasaran akan menyebabkan farmer's share yang diterima petani akan semakin kecil (Asmarantaka, 2009). Yang menjadi pertanyaan adalah 1) apakah semua tingkat pasar dalam pemasaran ternak sapi terintegrasi?, 2) apakah distribusi marjin pemasaran dan 3) farmer's share dalam pemasaran ternak sapi di wilayah ini sudah berjalan secara proporsional?

Berdasarkan latar belakang di atas, maka masalah yang perlu disimak dan di carikan solusinya adalah sebagai berikut : 1) berapa besar indeks keterpaduan pasar (index market conection) dalam pemasaran ternak sapi di Kabupaten Kupang, 2) berapa besarnya farmer's share yang dalam pemasaran ternak sap potong di Kabupaten Kupang? dan 3) bagaimana distribusi margin pemasaran di antara lembaga perantara belum berjalan secara proporsional.

\section{Metode}

Lokasi penelitian ini ditentukan secara Multiple Stage Mathod yaitu metode penentuan sampel bertahap ganda (Nazir, 2013; Bungin, 2014). Penentuan lokasi dilakukan bertahap yakni mulai kecamatan hingga desa secara purposive, namun dalam penentuan responden dilakukan secara acak sederhana (random sampling). Untuk menentukan pedagang perantara dan pedagang antar pulau dilakukan dengan metoda snow ball sampling (Silalahi, 2010).

\section{Metoda Pengumpulan Data}

Penelitian ini dilakukan dengan metoda survai. Pengumpulan data dilakukan melalui pengumpulan data primer dan data sekunder. Data prime dikumpulkan langsung dari petani dan pedagang perantara maupun pedagang antar pulau, dengan berpedoman pada daftar pertanyaan sudah dipersiapkan sebelumnya. Sedangkan untuk data sekunder dikumpulkan dari dinas atau instansi yang berhubungan dengan penelitian ini.

\section{Metoda Analisis Data}

Metoda yang digunakan untuk menganalisis data penelitian ini adalah analisis keterpaduan pasar pada : mulai dari petani, pedagang pengumpul desa/kecamatan, pedagang besar atau pedagang besar yang mengantar-pulaukan ternak sapi di Kabupaten Kupang-NTT. Analisis data secara kuantitaif dilakukan dengan pendekatan Analisis Integrasi Pasar secara vertikal baik dalam jangka pendek maupun dalam jangka panjang. Analisis Tampilan Pasar Untuk mengetahui tampilan pasar ternak sapi potong di Kabupaten Kupang dilakukan dengan analisis farmer's share, margin pemasaran dan distribusi share keuntungan di antara lembaga pemasaran yang terlibat dalam pemasaran ternak sapi di wilayah tersebut.

\section{Hasil dan Pembahasan}

\section{Sistem Pemasaran dan Penentuan Harga Ternak Sapi}

Pada umumnya petani di wilayah penelitian menjual ternak sapi melalu pedagang perantara $(72 \%)$ dan hanya $28 \%$ lainnya yang menjual langsung pedagang antar pulau. Alasan penjualan ternak sapi melalui pedagang perantara adalah 1) sudah saling mengenal sehingga jika petani mempunyai kebutuhan yang mendesak bisa meminta bantuan atau pinjaman kepada pedagang perantara dan jaminan sapi milikinya tidak akan dijual ke pihak lain, 2) jika menjual langsung ke pedagang antar pulau maka penetapan harga berdasarkan bera badan hidup, 3) ternak harus dibawa ke tempat penimbangan ternak yang pada umumnya di pasar hewan; 4) konsekuensi jauhnya tempat penimbangan ternak adalah jika terjadi kecelakaan dan ternak mengalami cedera dan mengalami patah kaki, maka ternak tersebut diafkir, 5) harga ternak afkir bisa turun hingga separuh bahkan lebih rendah lagi dari harga normal. Hasil penelitian ini relatif sama dengan hasil penelitian sebelumnya yang dilakukan Lalus (2010), di mana $74 \%$ petani menjual ternak sapi melalui pedagang perantara (belantik desa).

Rata-rata harga ternak sapi sebesar Rp. 8.765.677,97 jika penentuan harga berdasarkan berat hidup adalah sebesar.- dan rata-rata harga atas dasar taksiran berat badan sebesar Rp. 8.142.857,14.- dengan demikian terjadi selisih harga antara dua cara penentuan harga tersebut sebesar Rp. 622.820,82.- atau dapat dikatakan bahwa jika petani tidak menjual langsung ke pedagang antar pulau akan tetapi menjual melalui pedagang pedagang perantara/belantik desa, maka mereka akan kehilangan pendapatan sebesar $7.65 \%$.

Gambaran tentang saluran pemasaran ternak sapi potong di Kabupaten Kupang mulai dari tingkat petani peternak hingga pedagang besar penerima di Jakarta sebagai berikut

Beberapa saluran pemasaran ternak sapi di Kabupaten Kupang sebaga berikut :

1. Saluran pertama; petani $(\mathrm{Pf})$ menjual ke pedagang perantara dengan harga rata-rata Rp.7.134.984,90 per satuan ternak; kemudian dari pedagang perantara Pp) ke pedagang antar pulau (Pap) dengan harga rata-rata Rp. 9.247.076,90 per satuan ternak, selanjutnya Pap ke pedagang besar penerima (Wsr) di Jakarta dengan harga rata-rata Rp. 12.090.880,96 per satuan ternak dan dari pedagang besar penerima di Jakarta di jual ke RPH dan dari RPH ke konsumen dalam bentuk daging sapi.

2. Saluran kedua; petani ( $\mathrm{Pf})$ langsung menjual ke pedagang antar pulau (Pap) dengan harga rata-rata $\mathrm{Rp} 9.247 .076,90$ per satuan ternak selanjunya pedagang antar pulau menjual ke pedagang penerima di Jakarta dengan harga rata-rata $\mathrm{Rp}$. $12.090 .880,96$ per satuan ternak dan dar pedagang besar penerima di Jakarta - RPH - Konsumen daging sapi.

3. Saluran ketiga: petani $(\mathrm{Pf})$ menjual ternak bakalan : 1) langsung ke petani lain yang melakukan penggemukkan dengan harga rata-rata; Rp.4.880.952.38 dengan umur rata-rata ternak bakalan 19.98 bulan dan 2 ) melalui pasar hewan baik setelah ternak bakalan tersebut digemukkan selanjutnya dijual lagi seperti saluran saluran a) dan b).

4. Saluran keempat: petani (Pf) menjual langsung ke pedagang penjagal di RPH lokal (di Kupang), pada umumnya ternak sapi yang dijual petani langsung ke RPH setempat adalah ternak betina yang sudah tidak 
produktif lagi; maupun yang masih produktif tergantung desakan kebutuhan petani akan uang tunai, bahkan tidak jarang ternak sapi betina bunting sekalipun dijual. Harga rata-rata ternak betina yang dijual petani peternak adalah sebesar Rp.6.105.263,16.

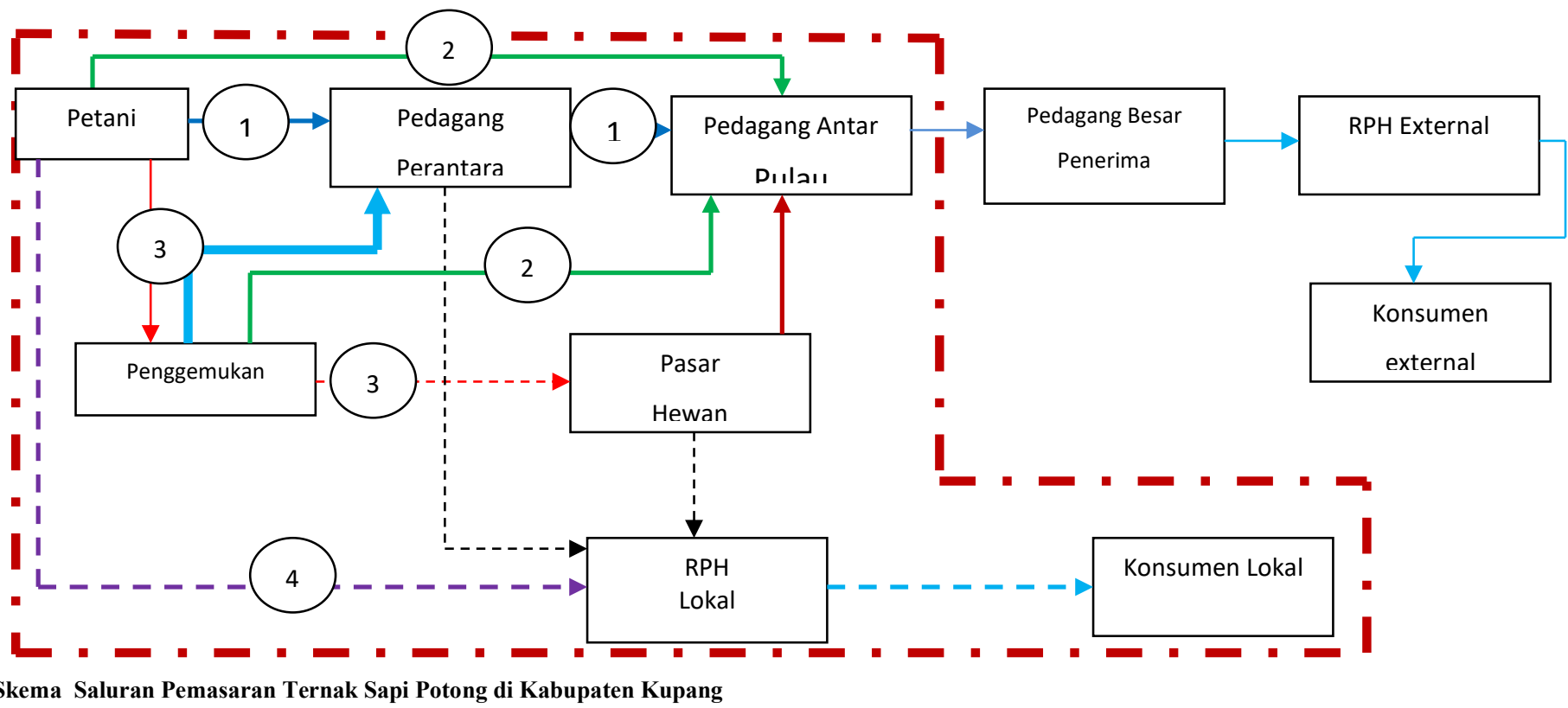

Pada saluran pertama, marjin pemasaran tercipta sebesar Rp.4.955.891,16. Nilai marjin sebesar itu, terdistribusi di antara pedagang perantara/belantik desa yang menerima Rp. 2.112.087,10 dan pedagang antar pulau menerima Rp.2.843.804,06. Distribusi margin seperti ini nampaknya merata, namun tidak adil di antara pedagang peranta dan pedagang antar pulau, karena resiko terbesar ada pada pedagang antar pulau, di samping itu jumlah dan komponen biaya terbesar ditanggung pedagang antar pulau.

Pada saluran kedua, petani langsung menjual kepada pedagang antar pulau sehingga rata-rata harga ternak sapi yang diterima petani (Pf) sebesar akan meningkat dari Rp.7.160.774,65 menjadi Rp.9.247.076,90 yang dibayar oleh pedagang antar pulau, berarti terjadi kenaikan rata-rata harga yang diterima petani sebesar Rp.2.112.087,10 (29.60\%). Marjin pemasaran pada saluran pemasaran kedua ini sebesar Rp. 2.843.804,06 yang diperoleh dari selisih antara harga yang diterima pedagang antar pulau Rp. 12. 090.880,96 dengan harga yang diterima petani Rp.9.247.076,90. Sedangkan margin pemasaran ternak sapi potong sebelumnya ketika petani tidak langsung menjual ke pedagang antar pulau melainkan melalui pedagang pengumpul sebesar Rp. 4.955.891,16; dengan demikian pada saat petani peternak langsung menjual ke pedagang antar pulau, maka margin pemasaran adalah sebesar Rp. 2.843.804,06 atau berkurang $42.62 \%$.

Ternak sapi yang diperdagangkan di Kabupaten Kupang, berasal dari petani yang tersebar di berbagai desa, selanjutnya petani lain membeli langsung dari petani pemilik di kediaman petani atau dapat juga dibeli di pasar hewan. Selanjutnya dilakukan penggemukkan (fattening) kemudian dijual melalui pedagang antar desa atau pedagang perantara dan seterusnya dijual ke pedagang antar pulau atau dijual ke rumah potong hewan untuk tujuan konsumen lokal bagi masyarakat kota Kupang dan sekitarnya. Di Kabupaten Kupang terdapat dua pasar hewan masing-masing Pasar Hewan Lili Kelurahan Camplong I Kecamatan Fatuleu dan pasar Baun Kecamatan Amarasi Barat.

Asmarantaka (2009) menyatakan bahwa secara teoritis, pemasaran yang efisien hanya terjadi dalam pasar persaingan sempurna. Akan tetap struktur pasar ini, tidak ditemukan dalam realita. Ukuran efisiensi adalah kepuasan konsumen, produsen maupun lembaga-lembaga yang terlibat dalam mengalirkan barang dari produsen sampai konsumen akhir; ukuran untuk menentukan kepuasan ini sulit dan sangat relatif, (Raju dan Oppen, 1992; Kohls dan Uhl, 2002 yang disitir Asmarantaka, 2009). Oleh sebab itu, kebanyakan pakar mempergunakan indicator efisiensi operasional dan efisiensi harga. Efisiensi pemasaran ternak sapi potong di Kabupaten Kupang-NTT dapat dilakukan melalui pendekatan market strucuture, market conduct, market performance (S-C-P) atau pendekatan struktur, perilaku dan tampilan pasar (Sudiyono, 2004, dan Asmarantaka, 2009).

\section{Struktur Pasar}

Salah satu alat analisis untuk menentukan struktur pasar adalah konsentrasi rasio dan elastisitas transmisi harga (Anindita dan Baladina, 2017) Konsentrasi rasio dimaksudkan sebagai jumlah ternak sapi potong yang dibeli oleh pedagang tertentu dibandingkan dengan jumlah ternak sapi potong yang diperdagangkan di pasar. Dalam penelitian ini ada 10 pedagang perantara yang membeli ternak sapi potong dari petani dengan volume transaksi berkisar antara 36 - 105 ekor atau berkisar antara $6.23 \%-17.21 \%$ setiap pedagang dari volume pembelian pasar.

Apabila disimak dari pedagang perantara yang jumlahnya hanya 10 orang dibandingkan dengan jumlah petani peternak yang berjumlah 100 orang, maka struktur pasar ternak sapi potong yang ada di Kabupaten Kupang NTT mempunyai tendensi ke arah persaingan oligopsoni. Selanjutnya apabila dilihat dari konsentrasi rasio di mana empat pedagang hanya menguasai $53.44 \%$ dari volume transaksi di pasar, dalam hal ini masih jauh dari syarat minimal $80 \%$, bahkan jika dilihat dari jumlah transaksi dari 8 pedagang saja baru mencapa $87.87 \%$ maka struktur pasar ternak sapi potong di wilayah ini mengarah ke persaingan oligopsoni dengan konsentrasi sedang.

Bila dilihat dari pedagang antar pulau yang jumlahnya hanya 4 orang, maka struktur pasar ternak sapi potong di Kabupaten Kupang NTT in mempunyai kecenderungan ke arah persaingan oligopsoni. Sedangkan hasil analisis konsentrasi rasio menunjukkan bahwa, dua pedagang antar pulau yang menguasai volume transaksi pasar sebesar $57.39 \%$, berarti struktur pasar ternak sapi potong di NTT mempunyai tendensi ke arah persaingan oligopoli dengan konsentrasi sedang. Bain (1959) yang disitir Erlinda, dkk (2008) menyatakan bahwa, setelah memahami tingkat konsentrasi pasar, karakteristik pasar dapat diidentifikasikan apakah monopoli, oligopoli, monopolistik atau persaingan sempurna.

Untuk mengetahui struktur pasar ternak sapi potong di Kabupaten Kupang, dapat dilakukan melalui analisis regresi linear sederhana. Analisis in dilakukan untuk mengetahui respon harga di tingkat petani peternak sebagai akibat kenaikan harga yang terjadi di tingkat pedagang antar pulau.

Koefisien regresi $(b=0.9534)$ untuk tingkat pasar antara petani dan pedagang perantara (Tabel 1) berarti, apabila terjadi perubahan harga di tingkat pedagang perantara sebesar $1 \%$ yang diberlakukan oleh pedagang antar pulau, maka perubahan harga tersebut akan ditransmisikan kepada petani peternak hanya sebesar $0.95 \%$, sehingga dapat dikatakan bahwa transmisi harga di antara pedagang perantara dan petani tidak berjalan secara sempurna; sehingga dikatakan struktur pasar antar pedagang perantara dan petani dalam keadaan bersaing tidak sempurna.

Untuk tingkat pasar antara petani dan pedagang antar pulau mempunyai koefisien regresi $(b=1.0653)$ menunjukkan bahwa apabila terjadi perubahan harga di tingkat pedagang antar pulau pasar sebesar $1 \%$, maka perubahan tersebut akan ditransmisikan kepada petani sebesar $1 \%$ juga, yang berarti transmisi harga di antara pedagang antar pulau dan petani berlangsung secara sempurna; hal ini berarti struktur pasar antar pedagang antar pulau dan petani bersaing sempurna.

\section{Perilaku Pasar}

Analisis perilaku pasar dilakukan untuk mengetahui praktek-praktek penentuan harga dalam pasar, baik secara kualitatif maupun kuantitatif. Praktekpraktek penentuan harga secara kualitatif diuraikan secara deskriptif. Sedangkan analisis kuantitatif dapat dijelaskan dengan bantuan analisis integrasi pasar secara vertikal yakni mulai dari tingkatan petani peternak sampai dengan pedagang antar pulau. Analisis integrasi pasar digunakan model regresi linear sederhana untuk jangka pendek maupun jangka panjang.

a. Praktek-Praktek Penentuan Harga. Adapun praktek penentuan harga oleh pedagang di Jakarta atas ternak sapi potong asal Nusa Tenggara Timur (khususnya Kabupaten Kupang) atau daerah lainnya di Indonesia maupun ternak impor berdasarkan tampilan fisik ternak yang bersangkutan. Di tingkat petani selaku produsen ternak sapi, pedaganglah yang bertindak selaku penentu harga dan petani hanya menerima harga 
Hal ini disebabkan oleh beberapa faktor antara lain, petani dalam memelihara ternak sapi hanya sebagai tindakan berjaga-jaga. Petani baru akan menjual ternaknya jika ada kebutuhan yang mendesak. Hal seperti ini sudah diketahui secara baik oleh para pedagang, sehingga ketika petani membutuhkan uang tunai untuk memenuhi kebutuhan-kebutuhan mendesak, maka harga ternak sapi menjadi rendah. Hal ini karena, dari sisi pedagang memiliki market power yang besar karena hanya beberapa pedagang saja (Tiku et al, 2012); sehingga membuat bargaining posisitionnya sangat kuat. Konsekwensinya para petani tidak mempunya pilihan terhadap harga yang diminta pedagang. Sementara itu tingkat, ada 3 kriteria ternak sapi potong yang diberlakukan oleh pedagang Jakarta yakni grade A adalah ternak sapi yang berbadan tambun (gemuk dan tampilan menarik), grade B adalah ternak sapi yang berbadan sedang dan grade $\mathrm{C}$ adalah yang berbadan tidak tambun, namun pada akhirnya penentuan harga berdasarkan berat badan hidup. Menurut Kurniawan (2014), tujuan penetapan harga adalah : 1) memperoleh keuntungan yang optimal, 2) membuat perusahaan tetap bertahan, 3) mencapai ROI (Return on Investment), menguasai pangsa pasar dan 5) mempertahankan status quo. Sementara itu menurut Arif Rahman (2010) yang disitir Kurniawan (2014) bahwa ada tiga tujuan dalam penetapan harga yaitu :1) berorientasi pendapatan, 2) berorientasi kapasitas dan 3) berorientasi pelanggan.

b. Analisis Integrasi. Integrasi pasar secara vertical bertujuan untuk menganalisis keterkaitan pasar di satu pasar dengan pasar di bawah atau di atasnya. Pada umumnya pedagang antar pulau memiliki catatan lengkap secara periodik dalam mingguan maupun bulanan tentang harga beli maupun harga jual ternak sapi potong yang berhasil diantar pulaukan selama tiga tahun yakni sejak 2011 sampai dengan 2013, harga ternak sapi cenderung bervariasi.

Harga Rata-rata ternak sapi potong pada berbagai tingkat pasar di tingkat petani pada tahun 2011 sebesar Rp. 5.251.086,96 pada tahun 2012 naik menjadi Rp. 5.422.093,02 kemudian naik lagi menjadi Rp. 6.283.823,53 pada tahun 2013, atau dalam kurun waktu 2011 sampai dengan tahun 2013 terjadi kenaikan harga sebesar $19.67 \%$. Walaupun terjadi kenaikan harga rata-rata pada peternak, akan tetapi justru penerimaan petani peternak menurun yakni pada tahun 2011 dari Rp. 8.051.666,67 menjadi $\mathrm{Rp}$ 7.065.151,52 atau terjadi penurunan harga sebesar $12.25 \%$ pada tahun 2012. Selanjutnya pada tahun 2013 terjadi lagi kenaikan penerimaan ratarata ternak sapi potong dari Rp. 7.065.151,52 menjadi Rp 12.567.647,06 atau terjadi kenaikan penerimaan sebesar $77.88 \%$.

\section{Integrasi Pasar Ternak Sapi Potong di Kabupaten Kupang}

Integrasi harga ternak sapi potong dalam jangka pendek antara petan peternak dengan pedagang perantara di Kabupaten Kupang ditunjukkan oleh koefisien regresi $(b 11=0.6921)$. Hasil pengujian secara statistik, koefisien yang ditemukan berbeda sangat nyata $(\mathrm{P}<0.01)$. Hal ini berarti apabila terjadi kenaikan harga di tingkat pedagang perantara sebesar $1 \%$, maka kenaikan harga tersebut akan ditransmisikan kepada petani hanya sebesar $0.69 \%$. Berarti persentase kenaikan harga yang diberlakukan pedagang perantara kepada petani peternak lebih kecil dari kenaikan harga yang diterima pedagang perantara sendiri Dengan demikian dapat dikatakan bahwa harga ternak sapi potong ditingkat peternak tidak terintegrasi secara sempurna dengan harga di tingkat pedagang perantara,(Sexton, King and Carman, 1991.).

Integrasi harga ternak sapi potong dalam jangka pendek antara petani peternak dengan pedagang antar pulau di Kabupaten Kupang ditunjukkan oleh koefisien regresi $(b 12=0.6596)$. Hasil pengujian secara statistik, koefisien regresi yang ditemukan berbeda sangat sangat $(\mathrm{P}<0.01)$. Hal ini berarti apabila terjadi kenaikan harga di tingkat pedagang antar pulau sebesar $1 \%$, maka kenaikan harga tersebut akan ditransmisikan kepada petani hanya sebesar $0.66 \%$. Berarti persentase kenaikan harga yang diberlakukan pedagang antar pulau kepada petani tidak sama dengan kenaikan harga yang diterima pedagang antar pulau dari pedagang di Jakarta. Dengan demikian dapat dikatakan bahwa harga ternak sapi potong ditingkat petani belum terintegrasi secara sempurna dengan harga di pedagang antar pulau. Goodwin dan Piggot (2001) menyatakan bahwa integrasi pasar membawa implikasi penting bagi penemuan harga dan berlangsungnya pasar semenjak adanya deviasi dari integrasi yang mungkin secara tidak langsung mengurangi peluang resiko keuntungan bagi para pedagang antar ruang.

Integrasi harga ternak sapi potong dalam jangka pendek antara pedagang perantara dengan pedagang antar pulau di Kabupaten Kupang ditunjukkan oleh koefisien regresi (b13 $=0.9868$ ). Hasil pengujian secara statistik, koefisien yang ditemukan berbeda sangat sangat $(\mathrm{P}<0.01)$. Hal ini berarti apabila terjadi kenaikan harga di tingkat pedagang antar pulau sebesar $1 \%$, maka akan kenaikan harga tersebut akan ditransmisikan kepada petani peternak sebesar $0.99 \%$ (dibulatkan menjadi 1\%). Berarti persentase kenaikan harga yang diberlakukan pedagang antara pulau kepada pedagang perantara sama dengan kenaikan harga yang diterima pedagang antar pulau dari pedagang di Jakarta. Dengan demikian dapat dikatakan bahwa harga ternak sapi potong ditingkat pedagang perantara terintegrasi secara sempurna dengan harga di tingkat pedagang antar pulau.

Pendekatan lain yang digunakan untuk mengetahui integrasi harga ternak sapi potong dalam jangka pendek di Kabupaten Kupang adalah Index of Market Connection (IMC). Dari hasil analisis diperoleh IMC antara harga ternak sapi potong di tingkat petani peternak dan pedagang perantara sebesar 1.0040; antara petani peternak dan pedagang antara pulau 1.0048; antara pedagang perantara dan pedagang antar pulau sebesar 1.0714. Nampak bahwa koefisien IMC $>0$ pada ketiga tingkat pasar ternak sapi potong di Kabupaten Kupang. Berarti dalam jangka pendek harga ternak sapi potong di ketiga pasar tidak teritegrasi secara sempurna, karena perubahan harga yang terjadi di tingkat pasar yang lebih tinggi tidak diteruskan secara secara sempunra ke tingkat pasar yang lebih rendah Dengan perkataan lain, apabila terjadi perubahan harga yang diberlakukan pedagang besar di Jakarta kepada pedagang antara pulau, maka perubahan harga tersebut tidak diteruskan secara efektif kepada pedagang perantara maupun kepada petani, hal ini tidak sesuai dengan pendapat Eronmown et al (2014) yang menyatakan bahwa keadaan tidak terintegrasinya pasar secara spasial antar dua pasar atau lebih disebabkan oleh salah satu faktor yaitu asimetri informasi.

Integrasi harga di tingkat petani dan pedagang perantara dalam jangka panjang ditunjukkan oleh koefisien regresi $(\alpha 2.1=0.5537<1)$, antara pedagang perantara dan pedagang antara $(\alpha 2.2=0.9278<1)$ dan antar petani dan pedagang antar pulau $(\alpha 2.3=0.4420<1)$.berarti dalam jangka panjang harga baik, di tingkat petani dan pedagang perantara, pedagang perantara dan pedagang antar pulau maupun antara petani dan pedagang antar pulau cenderung terintegrasi.

\section{Tampilan Pasar}

Untuk mengetahui tampilan pasar pada pemasaran ternak sapi potong di Kabupaten Kupang, dapat dilihat dari :

a. Farmer Share. Farmer share adalah bagian harga yang diterima petani peternak dari harga yang dibayar pedagang antar pulau. Hasil analisis menunjukkan bahwa harga rata-rata ternak sapi potong per ekor di Kabupaten Kupang yang dibayar oleh pedagang antar pulau pada tahun 2008, 2009 dan 2010 berturut-turut Rp. 6.616.008,20; Rp. 6.338.872.41 dan Rp.6.691.833.33 sedangkan harga rata-rata yang diterima petani peternak berturut-turut sebesar Rp. 4.409.344,26; Rp.4.519.827,59 dan Rp.5.424.074,07. Dengan demikian bagian harga yang diterima petani peternak (farmer's share) di Kabupaten Kupang berturut-turut $66.65 \%$ $71.31 \%$ dan $75.73 \%$ dari harga yang dibayar oleh pedagang antar pulau. Rata -rata farmer's share di Kabupaten Kupang adalah 75,95\%. Hasil analisis farmer's share di atas berarti pemasaran ternak, sudah berlangsung cukup adil, meskipun pada berbagai tingkatan pasar ternak sapi di wilayah ini belum terintegrasi secara sempurna. Hal ini mungkin disebabkan oleh sistem jual beli ternak sapi di daerah ini di mana pedagang antar pulau langsung membeli ternak dari petani, sehingga harga yang diterima sama besarnya dengan harga yang diterima pedagang perantara dari pedagang antar pulau.

b. Margin Pemasaran. Yang dimaksud dengan margin pemasaran dalam penelitian ini adalah perbedaan harga di tingkat pedagang antar pulau dengan harga di tingkat petani peternak. Analisis margin dilakukan untuk semua tingkatan pasar yang dilalui oleh ternak sapi potong mulai dari petani peternak sampai pedagang di Jakarta mempunyai margin pemasaran ternak sapi potong di Kabupaten Kupang masih tergolong cukup tinggi yakni $62.17 \%$.

c. Share Keuntungan Pedagang. Distribusi margin maupun keuntungan tidak merata di antara lembaga pemasaran yang terlibat dalam pemasaran ternak sapi potong di Kabupaten Kupang. Hal ini terlihat rasio keuntungan dan margin, di mana untuk pedagang perantara $88.57 \%$ dan pedagang antar pulau hanya $48.33 \%$. Rasio dari total keuntungan terhadap margin pemasaran sebesar $66.71 \%$. Dengan pendekatan ini juga mendukung pendekatan sebelumnya bahwa pemasaran ternak sapi potong di Kabupaten Kupang belum efisien.

Salah satu komponen biaya yang tergolong besar adalah penyusutan bobot badan ternak selama pengangkutan yang mencapai $15.40 \%$ dari total biaya pemasaran. Tingginya penyusutan bobot badan ternak ini disebabkan dalam pengantar-pulauan ternak sapi potong dari daerah ini ke Jawa (Jakarta) masih menggunakan kapal kargo, bukan menggunakan kapal yang dirancang khusus untuk tujuan ini. Sedangkan tingginya keuntungan pedagang perantara dibandingkan dengan pedagang antar pulau disebabkan oleh karena komponen biaya dalam jumlah maupun dalam nilai uang yang dikeluarkan para pedagang perantara tidak sebanyak/sebesar yang dikeluarkan pedagang antar pulau.

Salah satu strategi peningkatan penerimaan petani adalah dengan diasumsikan bahwa semua petani dalam menentukan harga jual ternak berdasarkan berat badan hidup. Hasil analisis data menunjukkan bahwa model regresi linear sederhana untuk 3 tingkatan pasar yakni petani peternak pedagang antar pulau $(\mathrm{Pf}-\mathrm{Pap})$, petani peternak - pedagang perantara $(\mathrm{Pf}-\mathrm{Pp})$ dan pedagang perantara - pedagang antar pulau ( $\mathrm{Pp}-\mathrm{Pap})$ sebagai berikut : a) Model regresi linear untuk tingkat pasar Pf-Pap
(2)

$$
\mathrm{LnPf}=0.1860+0.9709 \text { LnPap }
$$

$\begin{array}{cll}\text { Se } & : & (0.1127)(0.0072) \\ \text { tstat } & : & (1.6502)(134.2460) \\ \mathrm{t} 0.01 / 2 ;(80) & : & 1.645 ; \mathrm{R}^{2}=0.9959\end{array}$

Berdasarkan persamaan (2) nampak bahwa koefisien $\beta<1(b=0.9709)$, berarti struktur pasar ternak sapi potong di Kabupaten Kupang, antara petani dan pedagang antar pulau berada dalam keadaan bersaing sempurna. Berarti jika terjadi perubahan harga di Cikarang Jakarta sebagai pasar acuan sebesar 1\% terhadap pedagang antar pulau, maka perubahan harga tersebut diteruskan secara sempurna yakni sebesar $1 \%$ (dibulatkan) ke tingkat petani. Akibatnya perubahan harga yang terjadi tersebut dapat dengan segera dinikmati oleh tingkat pasar paling bawah dalam hal ini para petani. Hal ini berbeda dengan yang dinyatakan 
oleh Goodwin and Schroeder, 1991 yang disitir Pendel dan Schroeder (2006) bahwa pasar yang tidak terintegrasi akan merefleksikan informasi harga secara tidak tepat, atau yang sering dikatakan asimetri informasi pasar sehingga berdampak pada pasar yang tidak terintegrasi, sehingga tidak akan merefleksikan harga secara tepat.

b) Model regresi linear sederhana untuk tingkat pasar $\mathrm{Pf}-\mathrm{Pp}$

(3)

$$
\mathrm{LnPf} \quad=0.1176+0.9875 \mathrm{LnPp}
$$$$
0.01 / 2
$$

$$
\begin{aligned}
& \text { Se } \quad: \quad(0.0752)(0.0049)
\end{aligned}
$$

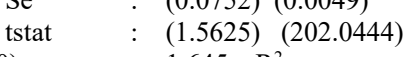$$
\text { : } 1.645 ; \mathrm{R}^{2} \quad=0.9982
$$

Persamaan (3) menunjukkan bahwa koefisien $\beta<1(b=0.9875)$, berarti struktur pasar ternak sapi potong di Kabupaten Kupang antara petani dan pedagang perantara berada dalam keadaan bersaing sempurna. Hal berarti apabila terjadi perubahan harga yang dialami oleh pedagang perantara sebesar $1 \%$, maka perubahan harga tersebut diteruskan secara sempurna yakni sebesar $0.9875 \%$ (dibulatkan menjadi 1\%) ke tingkat petani. Akibatnya perubahan harga yang terjadi tersebut dapat dengan segera dinikmati oleh tingkat pasar paling bawah dalam hal ini para petani.

\section{b) Model regresi linear sederhana untuk tingkat pasar Pp - Pap}

(4)

$$
\mathrm{LnPp}=0.0997+0.9813 \text { LnPap }
$$

$\begin{array}{cll}\text { Se } & : & (0.1164)(0.0075) \\ \text { tstat } & : & (0.8568)(131.4055) \\ \text { t0.01/2; (80) } & : & 1.645 ; \mathrm{R}^{2}=0.9957\end{array}$

Persamaan (4) menunjukkan bahwa koefisien $\beta<1(\mathrm{~b}=0.9813)$, berarti struktur pasar ternak sapi potong di Kabupaten Kupang antara pedagang perantara dan pedagang antar pulau berada dalam keadaan bersaing sempurna. Hal berarti apabila terjadi perubahan harga di pasar acuan, dalam hal ini pasar Cikarang Jakarta sebesar 1\% terhadap pedagang antar pulau, maka perubahan harga tersebut diteruskan secara sempurna yakni sebesar $0.9813 \%$ (dibulatkan menjadi $1 \%$ ) ke tingkat pedagang perantara. Akibatnya perubahan harga yang terjadi tersebut dapat dengan segera dinikmati oleh tingkat pasar dibawahnya (pedagang perantara).

\section{Simpulan}

IMC antara harga ternak sapi potong di tingkat petani dan pedagang perantara sebesar 1.0040; antara petani dan pedagang antara pulau 1.0048; dan antara pedagang perantara dan pedagang antar pulau sebesar 1.0714. Berarti dalam jangka pendek harga ternak sapi potong di ketiga pasar tidak teritegrasi secara sempurna.

Farmer's share dalam pemasaran ternak sapi di Kabupaten Kupang sudah berlangsung cukup adil, meskipun pada berbagai tingkatan pasar ternak sapi di wilayah ini belum terintegrasi secara sempurna. Rata-rata farmer's share adalah 75,95\%.

Margin pemasaran 62,17\%; profit margin $66.71 \%$. Profit margin terbesar diterima pedagang perantara yakni $60.70 \%$, pedagang antar pulau sebesar $29.30 \%$. Distribusi margin pemasaran masih timpang, yakni pedagang perantara $88.57 \%$ dan pedagang antar pulau sebesar $48.33 \%$

\section{Pustaka}

Anindita, R. 2004. Pemasaran Hasil Pertanian. Penerbit PAPYRUS. Jln Semolowaru Indah Blok I-15 Surabaya 60119.

Anindita, R.; Nur Baladina 2017. Pemasaran Produk Pertanian. Penerbit ANDI Yogyakarta.

Asmarantaka, Ratna Winandi 2009. Pemasaran Produk-Produk Pertanian. Bunga Rampai Agribisnis Seri Pemasaran. Penerbit Departemen Agribisnis Fakultas Ekonomi dan Manajemen Institut Pertanian Bogor.

Bungin, Burhan, 2014. Metodologi Penelitian Kuantitatif. Komunikasi, Ekonomi dan Kebijakan Publik Serta Ilmu-ilmu Sosial Lainnya. Penerbit Kencana Prenada Media Group, Jakarta.

Dahl, D.C. and J.W. Hammond,1977. Market and Price Analysis. The Agricultural Industries. Mc-Graw Hill Company Book, New York.

Erlinda, M; Vivi Evertina dan Rahmat Nurcahyo, 2008. Structure, Conduct, and Performance Analysis in Palm Cooking Oil Industry in Indonesia Using Structure, Conduct Performance Paradigm (SCP). Proceeding, International Seminar on Industrial Engineering and Management Santika Hotel Jakarta, October $25^{\text {th }}$, 2008. ISSN 1978-774X.Download April $25^{\text {th }}$ 2016 http://citeseerx.ist.psu.edu/viewdoc/download? Doi=10.1.1.663.4113\&rep=rep1\&type $=$ pdf.

Eronmown, I.; Alufohai, GO: ADA-Okungbowa, CI (2014). Structure, Conduct and Performance of Plantain Marketing in Edo State Nigeria. J.Appl.Sci.Environ.Manage. September 2014. Vol.18(3) 437-440. www.ajol.info and www.bioline org.br/ja. Jasem ISSN 1119-8362

Goodwin, Barry K. and Nicholas E. Piggott, 2001. Spatial Market Integration, in the Presence of Threshold Effects. American Journal of Agricultural Economics Association, 83(2) (May 2001): 302-6017
Djoko Susilo, Bahari, 2012. Integrasi Pasar Dan Efisiensi Ekonomi Usaha Ternak Sapi Potong Di Sulawesi Selatan, Sulawesi Tengah Dan Kalimantan Timur. Disertasi. Universitas Gajah Mada.

Kurniawan, Arief Rahman (2014). Total Marketing. Penerbit Kobis. J1 Imogir Barat RT 5 no 95 Bangunharjo Sewon Bantul Yogyakarta 55187.

Lalus, Matheos F. 2010. Strategi Peningkatan Penerimaan petani Peternak Tradisional Dalam Pemasaran Ternak Sapi Potong di Kabupaten Kupang Nusa Tenggara Timur. Laporan Penelitian. Fakultas Peternakan Universitas Nusa Cendana Kupang.

Lalus, M. F.; Z. Fanani; Bambang Ali Nugroho and Hari Dwi Utami, 2018. Analysis Of Beef Cattle Marketing In Kupang Regency, East Nusa Tenggara Province, Indonesia. Asian Academic Research Journal Of Multidisciplinary (AARJMD). Volume 5 Issue 5 (May 2018) ISSN : 2319 - 2801. http://www.asian academicresearch.org/maymd2018. html.

Muanga, Gertrude S. and Donald S. Snyder, 1997. Market Integration and the Law of One Price : Case Study of Selected Feeders Cattle Markets. Utah State University. Digital Commons@USU. Economic Research Institute Study Papers.

Pendell, Dustin L; and Ted C. Schroeder, 2006. Impact of Mandatory Price Reporting on Fed Cattle Market Integration. Journal of Agricultural and Resource Economics 31(3):568-579.

Ravallion, M. 1986. Testing Market Integration. American Journal of Agricultural Economic Association. Volume 72 Number 3.

Sexton, Richard J.; C. L. King and Hoy F. Carman, 1991. Market Integration, Efficiency of Arbitrage and Imperfect Competition. Methodology and application to U.S Celery. American Journal of Agricultural Economics. Vol. 73 Number 3, August 1991.

Sudiyono, A. 2004. Pemasaran Pertanian. Edisi kedua UMM Press, Penerbit Universitas Muhammadiyah Malang.

Tiku, N. E.; J. O. Olukosi; R.A. Omolehin and M. O. Oniah, 2012. The Structure, Conduct and Performance of Palm Oil Marketing in Cross River State, Nigeria. Journal of Agricultural Extension and Rural Development Vol.4(20), pp.569-573, December 2012. Available online at http://www.academicjournals.org/JAERD. DOI : 10.5897/JAERD12.151 ISSN 1990-3839 (C) 2012 Academic Journals. 